\title{
Corporate Social Responsibility Activities of Mining Companies: The Views of the Local Communities in Ghana
}

\author{
Yaw Brew1,2, Chai Junwu', Samuel Addae-Boateng1,2 \\ ${ }^{1}$ School of Management \& Economics, University of Electronic Science \& Technology of China, Chengdu, China \\ ${ }^{2}$ Faculty of Business and Management Studies, Koforidua Polytechnic, Koforidua, Ghana \\ Email: y.brew@yahoo.com
}

Received 1 June 2015; accepted 26 June 2015; published 29 June 2015

Copyright (C) 2015 by authors and Scientific Research Publishing Inc.

This work is licensed under the Creative Commons Attribution International License (CC BY). http://creativecommons.org/licenses/by/4.0/

c) (i) Open Access

\begin{abstract}
Mining companies in Ghana seem to have responded somehow over the years to the Corporate Social Responsibility (CSR) call but some still face open resistance from members of the communities who see them (mining companies) as socially irresponsible. The research sought to unearth the views and concerns of the local communities about the CSR activities of mining companies in the Ashanti, Eastern and Western regions of Ghana. The sample was drawn from the catchment communities of gold mining companies who had commercial membership, level A, with the Ghana Chamber of mines. The research established that there was indeed the existence of some health, education, community aid, and livelihood related CSR activities in the communities. The research revealed that most people, especially, in the Eastern region and the Western region had concerns about the lack of frequent medical screening by the mining companies. They are of the view that the operations of the mining companies have a negative effect on them (local community). The research concluded with some recommendations on how local community concerns could be addressed.
\end{abstract}

\section{Keywords}

Corporate Social Responsibility, Local Community, Mining Company

\section{Introduction}

The practical implications of Corporate Social Responsibility (CSR) have received much attention [1]-[5]. Research suggests that corporate social responsibility represents a differentiating factor that may be used success-

How to cite this paper: Brew, Y., Junwu, C. and Addae-Boateng, S. (2015) Corporate Social Responsibility Activities of Mining Companies: The Views of the Local Communities in Ghana. American Journal of Industrial and Business Management, 5, 457-465. http://dx.doi.org/10.4236/ajibm.2015.56045 
fully by firms to distinguish themselves within their industries. Proponents of this position believe that investors interested in using their decisions to effect social change are substantial in size and buying power. These investors are likely to frame their evaluations of alternative products or stock offerings within the context of the parent companies' alignment with their beliefs [1]. The primary way in which businesses are assessed by potential investors is through perceived corporate social performance (CSP); this indicator measures the ability of firms to meet or exceed the expectations of various stakeholder groups on important social issues [6].

An increasing number of studies, both in the practitioner and academic press, show that firms are becoming more conscientious of the effects of their socially responsible behaviour. Innovative responsible strategy, exceeding government requirements and considering multiple stakeholders, is a long-term objective. Initially, adoption of CSR burdens a company financially. But, investing resources in charity, environmental protection, and education pays dividends in corporate reputation. A relationship with employees, competitors, consumers, suppliers and the local communities is invaluable. Educated owners understand the importance of CSR. Increasingly, investors seek socially responsible firms and not just the highest current financial returns. The prolonged advantage of CSR ensures sustainable economic advantage and should be a long-term objective of any organization [7].

The main objective of the study is to assess the views and concerns of local mining communities with respect to:

- Health related CSR activities;

- Education related CSR activities;

- Community Aid related activities;

- Livelihood related CSR activities

\section{Literature Review}

\subsection{Definition of CSR}

Corporate social responsibility is widely used to describe the obligations and responsibilities that a company should have for its stakeholders. There have been a growing concern toward the issue of social responsibility [4] [5] [8] but there is no single definition of CSR mainly because the concept is ambiguous [9]-[14] and has been defined in various ways [15] [16].

Herzig and Moon [17], argues that CSR is conventionally associated with: business responsibility for society (compensating for negative externalities, contributing to welfare) and responsibility to society (accountability); responsible business conduct (to ensure market stability and probity); and the management of the corporation-society interface. Hill et al. [1] posits that corporate social responsibility is the economic, legal, moral, and philanthropic actions of firms that influence the quality of life of relevant stakeholders. Each of these constituencies, both individually and collectively, forms opinions about organizations through perceptions of firms' corporate social performance, which is characterized as summary judgments about CSR activities used by investors to make purchase decisions.

Similarly, Smith [7] is of the view that, companies have an obvious obligation to serve their shareholders. Owners trust firms to manage their investment and produce returns. However, stockholders are not the only party with an interest in a firm's activities. Firms affect numerous groups and individuals, both internally and externally, engendering a realm of responsibility far beyond the positive economic returns demanded by shareholders. Corporate social responsibility (CSR) defines organizational consideration of multiple stakeholders and global impact, beyond simple focus on maximization of shareholder wealth. Wood [6] believes that, business and society are not mutually exclusive but rather the two are interwoven and cannot be separated from each other.

The European Union defined corporate social responsibility as a concept whereby companies integrate social and environmental concerns in their business operations and in their interaction with their stakeholders on a voluntary basis. Being socially responsible means not only fulfilling legal expectations, but also going beyond compliance and investing "more" into human capital, the environment and the relations with stakeholders [18].

According to Slack [19], there is no standard definition for CSR in the extractive sector. Companies generally use the term or related ones such as "sustainability" to refer to commitments to respect environmental and human rights standards. Providing benefits to the local communities also tends to be part of extractive industries companies' definition of CSR. Many companies now produce annual CSR or "sustainable" reports that highlight these benefits and steps taken to protect the environment 


\subsection{CSR and the Community}

Corporate social responsibility is also about the integration of companies in their local setting, whether this be in Europe or world-wide. Companies contribute to their communities, especially to local communities, by providing jobs, wages and benefits, and tax revenues. On the other hand companies depend on the health, stability, and prosperity of the communities in which they operate. For example, they recruit the majority of their employees from the local labour markets, and therefore have a direct interest in the local availability of the skills they need. The reputation of a company at its location, its image as an employer and producer, but also as an actor in the local scene, certainly influences its competitiveness.

Companies also interact with the local physical environment. Some rely on a clean environment for their production or offering of services-either clean air or clean water or uncongested roads. There can also be a relationship between the local physical environment and the ability of business to attract workers to the region they are located in. On the other hand, business can also be responsible for a number of polluting activities: noise, light, water pollution, air emissions, contamination of soil, and the environmental problems associated with transport and waste disposal.

Many companies become involved in community causes, notably by means of provision of additional vocational training places, assisting environmental charities, recruitment of socially excluded people, provision of child-care facilities for employees, partnerships with communities, sponsoring of local sports and cultural events or donations to charitable activities.

The development of positive relations with the local community and thereby the accumulation of social capital is particularly relevant for non-local companies. Multinational companies increasingly use these relations to support the integration of their affiliates into various markets in which they are present. The familiarity of companies with the local actors, the local environment traditions and strengths is an asset from which they can capitalise [18].

\subsection{The Role of Mining in the Economy}

Ghana's mineral reserves are significant and the country's mineral endowment potential is well known internationally and documented. Ghana is the 9th largest world producer of gold [20]-[23]. Ghana's output, in terms of gold, increased by 2.1 percent to 97.8 tonnes in 2013 but its share in total gold output remained constant at 3 percent [21] [22]. Total foreign direct investments (FDI) into the minerals and mining sector, from 1984 to 2011 amounted to some USS11.2 billion with the large scale mining and the mine support services sub-sector employing about 27,000 people [22] [24] [25].

The minerals sector continues to exert significant influence on the country's current account position. Contributing 37.6 percent of total merchandize exports in 2013 as compared to 43 percent in 2012, the minerals sector continued to be a leading source of foreign exchange for the country. The role of this inflow in propping up the value of the currency cannot be underestimated. Without doubt, the downswing in mineral export revenue was a major causal factor for the steep depreciation of the local currency in 2013 [21].

\section{Methodology}

This section provides an overview of the method used for the study and how data were collected and analysed. The research is descriptive in nature and employs the survey method in assessing the views and concerns of local communities about CSR activities of mining companies operating in their communities.

The sample was drawn from communities where gold mining companies who have commercial membership, level A, with the Ghana Chamber of Mines operates. These companies operate in four out of the ten regions of Ghana. For the purposes of this study, local communities of three of these regions were purposively selected because, the only Ghana Chamber of Mines, level A, company that operates in the fourth region is the same company that operates in the third region that was selected.

This scope (catchment communities of gold mining companies having Commercial Level A membership with the Ghana Chamber of Mines) was considered because, the Ghana Chamber of Mines expects its members to operate under high ethical standards and operate responsibly [26].

Convenience sampling technique was employed in selecting the respondents within various communities from the Ashanti region, Eastern region, and Western region, as the researchers surveyed the opinions of those that were available at the times they visited the various research areas. Purposive Sampling was used to select 
opinion leaders, assemblymen, etc. within the various communities visited because, in our judgement, they could provide answers that would enhance the attainment of our objectives.

Our use of convenience and purposive sampling techniques were consistent with the works of Addae-Boateng et al. [27], Addae-Boateng et al. [28] and suggestions by De Vos [29] and Saunders et al. [30]. Descriptive statistics such tables, frequencies, and percentages, were used by the researchers to illustrate data necessary for the presentation and analysis of data obtained from the field.

We used data collected from 501 respondents from mining communities in the Western, Eastern and Ashanti regions. Out of this number, 173 representing $34.53 \%$ respondents were from the Western region, 163 representing $32.54 \%$ from the Ashanti region and 165 representing 32.93\% from the Eastern region. The questionnaire was made up of both closed-ended and open-ended questions and the questionnaires were personally administered; this offered the researchers the chance to personally explain the questions to some respondents who cannot read in a way that they can understand and answer.

\section{Results and Discussion}

\subsection{Demographic Characteristics of the Respondents}

Table 1 presents the socio-demographic characteristics of the sample used for the research. Among the total number of 501 respondents who took part in the research, $63.5 \%$ of them were men and $36.5 \%$ were women. $12.8 \%$ of the respondents were below the age of 21 years, $39.7 \%$ of the respondents were between the ages of 21 30 years, $27.1 \%$ respondents were between the ages of $31-40$ years, $13.6 \%$ were between the ages of $41-50$ years and $6.8 \%$ of the respondents were above 50 years. The proportion of respondents with middle school qualification was $24 \%$, technical/vocational school was $5.6 \%$, and Secondary/High school was $41.5 \%$, first degree and above accounted for $20.4 \%$ and primary school and below was $8.6 \%$. The proportion of respondents with an average monthly income less than GH $\$ 251$ (minimum wage in Ghana) was $37.7 \%$, monthly income between GH $\not 251$ - 450 was $29.3 \%$, between GH $\not 451-650$ was $11.8 \%$, GH $\not 651-850$ was $8.6 \%$, GH $\not 851-1050$ was $6.0 \%$ and above GH $\phi 1051$ was $6.6 \%$.

\subsection{CSR Activities of Mining Companies in the Communities}

Respondents' knowledge about the supposed existence of various CSR activities of mining companies in the communities was examined. The variables used are what mining companies who come under the commercial membership, level A, of the Ghana Chamber of Mines claim they do or have done for their catchment communities on their websites. These activities were categorized into four groups by the researchers, namely Health related, Education related, Community Aid related, and Livelihood related activities.

Table 1. Demographic characteristics of the respondents.

\begin{tabular}{|c|c|c|c|c|c|c|}
\hline Index & Attribute & Frequency & Percentage & Index & Attribute & Percentage \\
\hline \multirow{7}{*}{ Gender } & Male & 318 & 63.5 & \multirow{7}{*}{$\begin{array}{c}\text { Highest } \\
\text { Educational }\end{array}$} & & \\
\hline & Female & 183 & 36.5 & & & \\
\hline & Total & 501 & & & Middle School & 24.0 \\
\hline & & & & & Technical/Vocational & 5.6 \\
\hline & & & & & Secondary/High School & 41.5 \\
\hline & & & & & $1^{\text {st }}$ Degree and above & 20.4 \\
\hline & & & & & Primary or below & 8.6 \\
\hline \multirow{9}{*}{ Age } & Below 21 years & 64 & 12.8 & \multirow{9}{*}{$\begin{array}{l}\text { Average } \\
\text { Monthly } \\
\text { Income }\end{array}$} & & \\
\hline & 21 - 30 years & 199 & 39.7 & & Less than GHC 251 & 37.7 \\
\hline & 31 - 40 years & 136 & 27.1 & & & \\
\hline & $41-50$ years & 68 & 13.6 & & $251-450$ & 29.3 \\
\hline & \multirow{5}{*}{$\begin{array}{c}51-60 \text { years } \\
\text { Above } 60 \text { years }\end{array}$} & 26 & 5.2 & & $451-650$ & 11.8 \\
\hline & & \multirow[t]{4}{*}{8} & \multirow[t]{4}{*}{1.6} & & $4 J 1-030$ & 11.0 \\
\hline & & & & & $651-850$ & 8.6 \\
\hline & & & & & $851-1050$ & 6.0 \\
\hline & & & & & Above 1051 & 6.6 \\
\hline
\end{tabular}

Fieldwork May, 2015. 


\subsubsection{Health Related CSR Activities}

Table 2 presents the results of health related CSR activities from the responses of respondents from the three regions in Ghana. In the Ashanti region, 68 respondents representing 41.7\% acknowledged that mining companies have provided clinic and nurses' quarters for the communities, which was followed by clinic only, representing $22.7 \%$, clinic and medical equipment was the third highest, representing $20.2 \%$. In the Western Region, 61 respondents representing 35.3\% acknowledged the provision of Clinic, Screening and Treatment Sponsorship, followed by 46 respondents representing $26.6 \%$ who acknowledged the provision of clinics only, medical equipment was the third highest, representing $8.7 \%$ of respondents. Unlike the Ashanti and Western regions, 95 respondents representing $57.6 \%$ acknowledged the provision of clinics only, followed by clinic, Screening and Treatment Sponsorship, the third highest was one-time national health insurance payment representing

$7.9 \%$. Though similar in what each region acknowledges, there are differences in what most of the people in each of the regions acknowledges per the percentages.

Further analysis of the responses reveals that these facilities are not necessarily located in the same town or village of the respondents but at a location that they can access. The analysis also showed the frustrations of local peoples about the lack of frequent medical screening by the mining companies. These concerns were popular among respondents who are close to the operation site of the mining companies in all the regions, especially, in the Eastern region and the Western region.

\subsubsection{Education Related CSR Activities}

Table 3 presents the results of education related CSR activities from the respondents. In the Ashanti Region 46 respondents representing $28.2 \%$ acknowledge the existence of a school building and a scholarship scheme, followed by school buildings only, representing $21.5 \%$, school building and library was the third highest representing $16.6 \%$. In the Western Region, 51 respondents representing 29.4\% acknowledged the existence of more than two of these activities or projects (school building, library, sponsorships, teachers' bungalow, and books). 27 respondents representing $15.6 \%$ acknowledged the presence of a library, while, school building only, representing $14.5 \%$ was the third highest. In the Eastern Region, school buildings only, registered 88 respondents representing $53.3 \%$, followed by $15.2 \%$ of respondents who acknowledged the existence of more than two of the activities. Provision of books only, representing $7.9 \%$ was the third highest.

Further analysis of the responses revealed that, most of the school building projects are renovations to existing school buildings or an extension of a classroom block and not a complete school. It was also revealed in the Western region data analysis that the award of scholarship was an adhoc and not a permanent activity. In the Ashanti region respondents acknowledged the presence of scholarship scheme, but they are displeased about those people who finally get the scholarships, they attribute this to lack of transparency in awarding scholarship to students.

\section{Table 2. Health related CSR activities.}

\begin{tabular}{|c|c|c|c|c|c|c|}
\hline & \multicolumn{2}{|c|}{ Ashanti Region } & \multicolumn{2}{|c|}{ Western Region } & \multicolumn{2}{|c|}{ Eastern Region } \\
\hline & Frequency & $\begin{array}{l}\text { Valid } \\
\text { Percent }\end{array}$ & Frequency & $\begin{array}{l}\text { Valid } \\
\text { Percent }\end{array}$ & Frequency & $\begin{array}{l}\text { Valid } \\
\text { Percent }\end{array}$ \\
\hline Clinic & 37 & 22.7 & 46 & 26.6 & 95 & 57.6 \\
\hline Nurses' Quarters & 3 & 1.8 & 2 & 1.2 & 9 & 5.5 \\
\hline Screening and treatment sponsorship & 2 & 1.2 & 13 & 7.5 & 8 & 4.8 \\
\hline Medical equipment & 7 & 4.3 & 15 & 8.7 & 7 & 4.2 \\
\hline One-time national Health Insurance payment & 2 & 1.2 & 13 & 7.5 & 13 & 7.9 \\
\hline Clinics \& Medical equipment & 33 & 20.2 & 11 & 6.4 & 8 & 4.8 \\
\hline Clinics \& Screening \& Treatment Sponsorship & 10 & 6.1 & 61 & 35.3 & 14 & 8.5 \\
\hline Clinics \& Nurses' quarters' & 68 & 41.7 & 11 & 6.4 & 2 & 1.2 \\
\hline Nurses Quarters \& Screening \& Treatment Sponsorship & 1 & 0.6 & 1 & 0.6 & 9 & 5.5 \\
\hline Total & 163 & 100.0 & 173 & 100.0 & 165 & 100.0 \\
\hline
\end{tabular}

Fieldwork May, 2015. 
Table 3. Education related CSR activities.

\begin{tabular}{|c|c|c|c|c|c|c|}
\hline & \multicolumn{2}{|c|}{ Ashanti Region } & \multicolumn{2}{|c|}{ Western Region } & \multicolumn{2}{|c|}{ Eastern Region } \\
\hline & Frequency & $\begin{array}{l}\text { Valid } \\
\text { Percent }\end{array}$ & Frequency & $\begin{array}{l}\text { Valid } \\
\text { Percent }\end{array}$ & Frequency & $\begin{array}{c}\text { Valid } \\
\text { Percent }\end{array}$ \\
\hline School Building & 35 & 21.5 & 25 & 14.5 & 88 & 53.3 \\
\hline Library & 18 & 11.0 & 27 & 15.6 & 8 & 4.8 \\
\hline Sponsorships & 2 & 1.2 & 19 & 11.0 & 7 & 4.2 \\
\hline Teachers Bungalow & 6 & 3.7 & 3 & 1.7 & 5 & 3.0 \\
\hline Books & 1 & 0.6 & 8 & 4.6 & 13 & 7.9 \\
\hline School Building \& Library & 27 & 16.6 & 10 & 5.8 & 5 & 3.0 \\
\hline School Building \& Scholarship & 46 & 28.2 & 24 & 13.9 & 6 & 3.6 \\
\hline School Building \& Teachers Bungalow & 6 & 3.7 & 5 & 2.9 & 4 & 2.4 \\
\hline School Building \& Books & 6 & 3.7 & 1 & 0.6 & 4 & 2.4 \\
\hline More than two activities/projects & 16 & 9.8 & 51 & 29.4 & 25 & 15.2 \\
\hline Total & 163 & 100.0 & 173 & 100.0 & 165 & 100.0 \\
\hline
\end{tabular}

Fieldwork May, 2015.

\subsubsection{Community Aid Related Activities}

Table 4 presents the results of Community Aid related activities from the respondents. In the Ashanti region, 64 respondents (39.3\%) acknowledged that the mining company has provided the community with boreholes for water. 25 respondents $(15.3 \%)$ mentioned the existence of boreholes and community roads, 19 respondents $(11.7 \%)$ admitted that the mining company has provided more than two of following; community centre, borehole, community road, and electricity. 41 respondents (23.7\%) from the Western region, disclosed that the mining company has provided their community with more than two of following; community centre, borehole, community road, and electricity. 26 respondents $(15 \%)$ admitted that the mining company has provided them with electricity, that is to say that the mining company help the community to be connected to the national grid, 25 respondents (14.5) admitted the existence of boreholes for water. The responses from the Eastern region were not so different from the other two regions, 76 respondents (46.1\%) acknowledged the provision of borehole facilities for the community, followed by 19 respondents (11.5) who agrees to the provision of community centres and 19 respondents $(11.5 \%)$ who admits that the mining company has provided more than two of following; community centre, borehole, community road, and electricity.

It could be seen from the analysis that the provision of borehole facilities to communities by mining companies had the highest percentage of respondents, especially, in the Ashanti and Eastern regions and the second highest in the Western regions. This maybe the fact that water is basic human need and/or the construction of a borehole facility is the cheapest in terms of cost among the other three variables (building of community centre, construction of community roads, and electricity).

Further analysis of the responses revealed the displeasure and bitterness of the local communities in the Western and Eastern regions about the deplorable state of their road which serves as the main route for mining company's vehicles and that of the communities. Some respondents in the Western region stated that the dust from the road disturbs them a lot but it is watered down only when the company senses an impending demonstration.

\subsubsection{Livelihood Related CSR Activities}

Table 5 presents the results of Livelihood related CSR initiatives from of respondents. In the Ashanti region 79 respondents (48.5\%) acknowledged that the mining company has offered employment to some local people, whiles 44 respondents (27\%) acknowledged the training and employment of local people. 14 respondents (8.6\%) acknowledged that the mining company has given vocational and technical training to some local people. In the Western region 59 respondents (34.1\%) acknowledged the provision of training (training in mobile phone re- 
Table 4. Community aid related activities.

\begin{tabular}{ccccccc}
\hline & \multicolumn{2}{c}{ Ashanti Region } & \multicolumn{2}{c}{ Western Region } & \multicolumn{2}{c}{ Eastern Region } \\
\cline { 2 - 7 } & Frequency & $\begin{array}{c}\text { Valid } \\
\text { Percent }\end{array}$ & Frequency & $\begin{array}{c}\text { Valid } \\
\text { Percent }\end{array}$ & Frequency & $\begin{array}{c}\text { Valid } \\
\text { Percent }\end{array}$ \\
\hline Community Centre & 3 & 1.8 & 13 & 7.5 & 19 & 11.5 \\
Boreholes & 64 & 39.3 & 25 & 14.5 & 76 & 46.1 \\
Community Roads & 5 & 3.1 & 8 & 4.6 & 14 & 8.5 \\
Electricity & 4 & 2.5 & 26 & 15.0 & 3 & 1.8 \\
Community Centre \& Boreholes & 4 & 2.5 & 18 & 10.4 & 4 & 2.4 \\
Community Centre \& Community Roads & 7 & 4.3 & 8 & 4.6 & 4 & 2.4 \\
Community Centre \& Electricity & 11 & 6.7 & 6 & 3.5 & 2 & 1.2 \\
Boreholes \& Community Roads & 25 & 15.3 & 3 & 1.7 & 7 & 4.2 \\
Boreholes \& Electricity & 8 & 4.9 & 10 & 5.8 & 7 & 4.2 \\
Community Roads \& Electricity & 13 & 8.0 & 15 & 8.7 & 10 & 6.1 \\
More than two activities/projects & 19 & 11.7 & 41 & 23.7 & 19 & 11.5 \\
Total & 163 & 100.0 & 173 & 100.0 & 165 & 100.0 \\
\hline
\end{tabular}

Fieldwork May, 2015.

Table 5. Livelihood related CSR activities.

\begin{tabular}{|c|c|c|c|c|c|c|}
\hline & \multicolumn{2}{|c|}{ Ashanti Region } & \multicolumn{2}{|c|}{ Western Region } & \multicolumn{2}{|c|}{ Eastern Region } \\
\hline & Frequency & $\begin{array}{c}\text { Valid } \\
\text { Percent }\end{array}$ & Frequency & $\begin{array}{l}\text { Valid } \\
\text { Percent }\end{array}$ & Frequency & $\begin{array}{l}\text { Valid } \\
\text { Percent }\end{array}$ \\
\hline Training of Local People & 14 & 8.6 & 14 & 8.1 & 21 & 12.7 \\
\hline Employment & 79 & 48.5 & 53 & 30.6 & 43 & 26.1 \\
\hline $\begin{array}{l}\text { Agricultural inputs or a plantation } \\
\text { project that the local people can live on }\end{array}$ & 2 & 1.2 & 23 & 13.3 & 40 & 24.2 \\
\hline Training of Local People \& Employment & 44 & 27.0 & 3 & 1.7 & 3 & 1.8 \\
\hline Training of Local People \& Plantations & 6 & 3.7 & 8 & 4.6 & 7 & 4.2 \\
\hline Employment \& Plantations & 7 & 4.3 & 13 & 7.5 & 8 & 4.8 \\
\hline Training, Employment \& Plantation project & 11 & 6.7 & 59 & 34.1 & 43 & 26.1 \\
\hline Total & 163 & 100.0 & 173 & 100.0 & 165 & 100.0 \\
\hline
\end{tabular}

Fieldwork May, 2015.

pairs), employment, and plantation projects. 53 respondents (30.6\%) acknowledged that the mining company has offered employment to local people, followed by agricultural inputs or a plantation project that the local people can live on, representing 13.3\%. In the Eastern region 43 respondents (26.1\%) acknowledged that the mining company has offered employment to local people, 43 respondents (26.1) acknowledged the provision of technical training (driving of heavy duty vehicles), employment, and plantation projects. The third highest was the provision of agricultural inputs or a plantation project that the local people can live on, which represent $24.2 \%$ of the respondents.

Analyses of the questions which asked respondents to express how they feel about the livelihood initiatives revealed that, their responses are just in acknowledgement that such initiatives have existed or exist but not a confirmation of their satisfaction towards them.

Most respondents are not happy about the fact that very few people from the communities are given employ- 
ment. Some respondents also alleged that some people who are not from the catchment communities have been employed under the pretence that they come from the community by some corrupt officers in the company; they alleged bribery in employing people by some officers. These reports of alleged bribery are related to the respondents from only the Western and Eastern regions. In the Eastern region, most respondents suspect the mining firm of occasionally practicing "non-existence" job vacancy announcements. They complain that after queuing for hours for the ballot to be drawn, the one or two people selected are never called for interview or to start work.

\section{Conclusions}

The community within which mining companies operate is one of the essential stakeholders of the company and for that matter mining companies must be sure to understand very well the community's views and concerns of the CSR activities that companies offer to their communities. The respondents acknowledge the existence of some health related, education related, community aid related, and livelihood related CSR activities in their community but they also have some concerns about them. On the health related CSR activities, most people, especially in the Eastern region and the Western region, have concerns about the lack of frequent medical screening by the mining companies; they are of the view that the operations of the mining companies have a negative effect on them. It is recommended that mining firms should occasionally, but frequently ensure health screening and help the locals who have health problems in relation with the operations of the company.

The study recommends mining companies to ensure that scholarship they award to students is transparent and gets to the right people. The mining companies should do background checks of workers who are recruited because it is assumed they come from the community to avoid giving jobs to people who are not from affected communities but seek employment under the guise of being community members.

Demonstrations and agitations of mining communities in Ghana against mining companies have been well reported by the media. These agitations and demonstrations do not normally end well and at the end deepen the negative perceptions people have about mining in the country, and most of these demonstrations bother on issues of social responsibility.

Mining companies must come out with clear guidelines on CSR, so that it takes care of the critical needs of the communities. Investment in CSR benefits the company in the long run.

\section{Limitations and Further Research}

This research concentrated on corporate social responsibility activities of gold mining companies who have commercial level "A" membership with the Ghana Chamber of Mines. Future research could include other mining companies who mine other minerals such as diamond and bauxite in Ghana. Also, future research could include mining companies with different membership category from the Ghana Chamber of Mines.

\section{References}

[1] Hill, R.P., Ainscough, T., Shank, T. and Manullang, D. (2007) Corporate Social Responsibility and Socially Responsible Investing: A Global Perspective. Journal of Business Ethics, 70, 165-174. http://dx.doi.org/10.1007/s10551-006-9103-8

[2] Mackenzie C. (2007) Boards, Incentives and Corporate Social Responsibility: The Case for a Change of Emphasis. Corporate Governance, 15, 935-943. http://dx.doi.org/10.1111/j.1467-8683.2007.00623.x

[3] Jones, B., Bowd, R. and Tench, R. (2009) Corporate Irresponsibility and Corporate Social Responsibility: Competing Realities. Social Responsibility Journal, 5, 300-310. http://dx.doi.org/10.1108/17471110910977249

[4] Pedersen, E.R.G. (2011) All Animals Are Equal, But ...: Management Perceptions of Stakeholder Relationships and Societal Responsibilities in Multinational Corporations. Business Ethics: A European Review, 20, 177-191. http://dx.doi.org/10.1111/j.1467-8608.2011.01618.x

[5] Hilson, G. (2012) Corporate Social Responsibility in the Extractive Industries: Experiences from Developing Countries. Resource Policy, 37, 131-137. http://dx.doi.org/10.1016/j.resourpol.2012.01.002

[6] Wood, D.J. (1991) Corporate Social Performance Revisited. Academy of Management Review, 16, 691-718.

[7] Smith, A.D. (2007) Making the Case for the Competitive Advantage of Corporate Social Responsibility. Business Strategy Series, 8, 186-195. http://dx.doi.org/10.1108/17515630710684187 
[8] Jones, B., Bowd, R. and Tench, R. (2009) Corporate Irresponsibility and Corporate Social Responsibility: Competing Realities. Social Responsibility Journal, 5, 300-310. http://dx.doi.org/10.1108/17471110910977249

[9] Lantos, G.P. (2001) The Boundaries of Strategic Corporate Social Responsibility. Journal of Consumer Marketing, 18, 595-632. http://dx.doi.org/10.1108/07363760110410281

[10] Galbreath, J. (2009) Building Corporate Social Responsibility into Strategy. European Business Review, 21, $109-127$. http://dx.doi.org/10.1108/09555340910940123

[11] Shahin, A. and Zairi, M. (2007) Corporate Governance as a Critical Element for Driving Excellence in Corporate Social Responsibility. International Journal of Quality \& Reliability Management, 24, 753-770. http://dx.doi.org/10.1108/02656710710774719

[12] Carroll, A.B. (1999) Corporate Social Responsibility: Evolution of a Definitional Construct. Business \& Society, 38, 268-295. http://dx.doi.org/10.1177/000765039903800303

[13] McWilliams, A. and Siegel, D. (2001) Corporate Social Responsibility: A Theory of the Firm Perspective. Academy of Management Review, 26, 117-127.

[14] Ralston, E.S. (2010) Deviance or Norm? Exploring Corporate Social Responsibility. European Business Review, 22, 397-410. http://dx.doi.org/10.1108/09555341011056177

[15] Dahlsrud, A. (2006) How Corporate Social Responsibility Is Defined: An Analysis of 37 Definitions. John Wiley \& Sons, Ltd., and ERP Environment. www.interscience.wiley.com

[16] Carroll, A.B. (1979) A Three-Dimensional Conceptual Model of Corporate Social Performance. Academy of Management Review, 4, 497-505.

[17] Herzig, C. and Moon, J. (2013) Discourses on Corporate Social Ir/Responsibility in the Financial Sector. Journal of Business Research, 66, 1870-1880. http://dx.doi.org/10.1016/j.jbusres.2013.02.008

[18] European Commission (2001) Promoting a European Framework for Corporate Social Responsibilities. DOC/01/9, Brussels.

[19] Slack, K. (2012) Mission Impossible?: Adopting a CSR-Based Business Model for Extractive Industries in Developing Countries. Resource Policy, 37, 179-184. http://dx.doi.org/10.1016/j.resourpol.2011.02.003

[20] Aryee, B.N.A. (2001) Ghana's Mining Sector: Its Contribution to the National Economy. Resource Policy, 27, 61-75. http://dx.doi.org/10.1016/S0301-4207(00)00042-8

[21] Ghana Chamber of Mines (2013). http://ghanachamberofmines.org/media/publications/Performance_of the_Mining_Industry_in_2013.pdf

[22] Boakye, D., Dessus, S., Foday, Y. and Oppong, F. (2012) Investing the Mineral Wealth in Development Assets: Ghana, Liberia and Sierra Leone. World Bank.

[23] Aryee, J., Soreide, T., Shukla, G.P. and Le, T.M. (2011) Political Economy of the Mining Sector in Ghana. The Wold Bank (WPS5730).

[24] Puplampu, B.B. and Dashwood, H.S. (2011) Organizational Antecedents of a Mining Firm's Efforts to Reinvent Its CSR: The Case of Golden Star Resources in Ghana. Business and Society Review, 116, 467-507. http://dx.doi.org/10.1111/j.1467-8594.2011.00393.x

[25] Ministry of Finance, Ghana (2014). http://www.mofep.gov.gh/?q=news/270912

[26] Ghana Chamber of Mines (2014). http://ghanachamberofmines.org/en/our-members/represented-level-a.php

[27] Addae-Boateng, S., Ayittah, S.K. and Brew, Y. (2013) Problems and Prospects of Selling in Reseller Markets in the Fast Moving-Consumer-Goods (FMCG) Industry Using the Sales Force; the Case of Y\&K Investments Limited, Koforidua, Ghana. Journal of Business and Management, 5, 124-139.

[28] Addae-Boateng, S., Wen, X. and Brew, Y. (2014) Governance Issues in Family Business: The Views of Family-Member-Employees, Non-Family-Member-Employees, and Management. International Journal of Economics, Commerce and Management, 2, 1-28.

[29] De Vos, A.S. (1998) Research at Grass Roots: A Primer for the Caring Professions. Van Schaik Publishers, Pretoria.

[30] Saunders, M.N.K., Lewis, P. and Thornhill, A. (2012) Research Methods for Business Students. 6th Edition, Financial Times/ Prentice Hall, New Jersey, 728. 